\title{
Solitary rectal ulcer syndrome
}

INSERM

\section{Source}

INSERM. (1999). Orphanet: an online rare disease and orphan drug data base. Solitary rectal ulcer syndrome. ORPHA:209964

Solitary rectal ulcer syndrome (SRUS) is a rare rectal disease characterized by rectal bleeding, abdominal pain, passage of mucus, sensation of incomplete evacuation, straining at defecation and rectal prolapsed, secondary to ischemic changes in the rectum. 